28 Knutson, Playing Companies and Commerce, 62.

29 Leggatt, Jacobean Public Theatre, 4.

\title{
Repertory and Riot: The Relocation of Plays from the Red Bull to the Cockpit Stage
}

On 4 March 1617 the newly built Cockpit playhouse in Drury Lane was assailed by a band of 'lewde and loose persons, apprentices and others. ${ }^{1}$ Writing four days after the event, Edward Sherbourne claimed that between three and four thousand apprentices had mobilized themselves, 'wounded divers of the players, broke open their trunckes, $\&$ whatt apparreil, bookes, or other things they found, they burnt $\&$ cutt in peeces; $\&$ not content herewith, gott on the top of the house, $\&$ untiled it'. ${ }^{2}$ Consequences were not limited to loss of property. Sherbourne elaborates that 'one prentise was slaine, being shott throughe the head with a pistoll, \& many other of their fellowes were sore hurt. ${ }^{3}$ On the same day, John Chamberlain wrote to Dudley Carleton of the disorder in town, adding that the players of Queen Anne's Men, the current occupants of the Cockpit, 'defended themselves as well as they could and slew three of them [the rioters] with shot, and hurt divers.' ${ }^{4}$ The gravity of the situation, at least as far as city authorities were concerned, is clear. In a letter to the lord mayor and aldermen of London, it was reported that 'there were diverse people slayne, and others hurt and wounded'. Later that month, the privy council ordered security and vigilance against the behaviour of citizens and apprentices to be tightened. ${ }^{5}$

A number of historical narratives have prioritized the riot, which took place on Shrove Tuesday that year. It has become representative of an English tradition and folklore of misrule, and functions as a crucial underpin to constructions of the role and social status of the 'suburban' apprentice in early modern England. ${ }^{6}$ Within the historiography of rioting its intensity is foreshadowed only by the notorious Evil May-Day riot of 1517, and amplified in the terse political demonstrations of the 1640s. ${ }^{7}$ It has also been assigned particular privilege in theatre history, and grants the Cockpit theatre and its repertory a central position in enduring narratives. Charles J. Sisson first established its importance to theatre history, positing a direct causal relationship between the riot and the recent transfer of Queen Anne's Men from the old Red Bull to the new Cockpit theatre, built and managed by Christopher 
Beeston. For Sisson, Beeston's transfer to the Cockpit constituted a 'desertion of the Red Bull' which, compounded by a lawsuit involving Beeston that became 'a matter of local notoriety', justified grounds for retaliation. ${ }^{8}$ Since then, a series of readings that have worked to establish its specificity to theatre history have causally linked the riot to Beeston's company transfer. ${ }^{9}$ Andrew Gurr and other critics attribute the events of that 1617 Shrove Tuesday to the anger of the Red Bull audience at the removal of citizen plays from an affordable playhouse, the crowd 'in protest at having their plays taken away from the penny playhouse and transferred to a sixpenny venue'. ${ }^{10}$ This account accommodates the historical facts of the 1617 riot, while recognizing from a theatre-historical perspective that Beeston's control over the company entailed the migration of a repertory from one theatre to another, as well as the transfer of players and their props. For the Red Bull audience it was the reclamation of a repertory that was at stake in the attack on the prohibitively expensive, alternative venue, their favourite plays now unavailable in a transfer that was indefinite, if not permanent. ${ }^{11}$

The narrative of a repertory-motivated riot acts as a defining moment in seventeenth-century theatre history and is now a familiar feature of the critical landscape. Essentially unchallenged, its endurance is related in part to the argument's appealing commitment to the importance of theatre: the premise that early modern audiences cared about repertory, and that plays made a difference to their lives. Accounts of the riot in which company transfer plays a central role figure 'the group' of participants (by implication, or explicitly, as here) as 'large, homogenous, organized, and intent on achieving their $[$ sic $]$ goals. ${ }^{12}$ This analysis envisages the Red Bull audience members as a fiercely local and loyal core of playgoers, with clearly delineated tastes and intimidating agency. They were prepared to act on their preference for particular plays in a manner that was both deliberate and strategic. The riot thus represents an extreme expression of audience demand, where the nature of plays available to particular audiences was a potentially inflammatory consideration in repertory management. The linkage between audience and repertory that this approach performs is also congruent with the current critical development of repertory-based methodologies, which seek to identify and define connections between theatrical repertories and the conditions in which they were created and performed. ${ }^{13}$ By situating transgression in Beeston's relocation of repertory, the current riot narrative affirms the Red Bull repertory's strong association with its audience by establishing a close 
relationship between the theatre and the demands, both economic and aesthetic, of its surrounding community.

Yet in the particular case of the Red Bull, the enduring connection between audience and repertory has proved limiting and problematic. Known for its spectacular, 'teare-throat', 'drum-and-trumpet' plays, the Red Bull's reputation is founded on its provision of cheap entertainment for 'Citizens, and the meaner sort of People. ${ }^{14}$ The design of its plays is consistently assumed to have sated the undiscerning appetites of 'ignorant asses' and 'Greasie-apron' 'Fishwiues'. ${ }^{15}$ Marta Straznicky has noted how, even in the seventeenth century, the Red Bull audience 'represents the general vulgarity of the playgoing public, meaning specifically lack of wit, learning, or mental acuity'. ${ }^{16}$ Interpretation of the Red Bull repertory according to the aesthetic preferences of a dull, spectacle-hungry, and reportedly violent audience has been debilitating and at times disastrous for the prioritization and critical reception of its plays. ${ }^{17}$ Plays that belonged to the Red Bull repertory in 1617 include Heywood's The Rape of Lucrece, with its 'reprehensible concession[s] to the taste of the audience at the Red Bull';18 his Ages serialization - a sequence of 'vulgarized' myths, 'with a superabundance of dumb-shows, spectacles, and machines'; ${ }^{19}$ and (possibly) Kirke's Seven Champions of Christendom, exemplary of 'the sort of spectacular, naïve, and formless piece that one learns to associate with the Red Bull theatre'. ${ }^{20}$ While repertory-motivated readings of the 1617 riot in no way endorse these critical views, ${ }^{21}$ they do perform the link between low audience and a particular kind of repertory that encouraged stereotypical perceptions of the Red Bull's clientele and plays in the past. The drum-and-trumpet repertory is thought to belong in some important sense to the amphitheatre and its audience: it was written for the citizens and achieved its greatest recognition there, stirring its followers into a passionate 'act of revenge'. ${ }^{22}$

Yet recent work has suggested that both the Red Bull's repertory content and the mental capacity of its audience resist straightforward categorization; arguing for this resistance, this work also suggests that the relationship between repertory and audience in this particular case may require rethinking. In a collection of essays in Early Theatre, Lucy Munro notes the courtly links of the Red Bull repertory and remarks that although ' $[t]$ he reputations of the Red Bull and its audience were in development from a remarkably early point in the theatre's history, ... they were not stable or static. ${ }^{23}$ Straznicky has analyzed the extent to which critics can attribute an identifiable or characteristic Red Bull repertory to its preservation and marketing in print, 
which may represent only one aspect of a repertory that, in performance, was less distinctive and much more diverse. While it remains unclear how far the readership of the Red Bull plays overlapped with their theatrical audience, Straznicky suggests that 'the persistent representations of the low literacy of this audience may obscure the extent to which the famously spectacledriven Red Bull repertory intersects with early modern print culture'. She thus suggests that 'a reassessment $\ldots$ of the social and educational make-up of the audience' is due, in an attempt to widen 'our sense of the social range of Red Bull playgoers.' ${ }^{24}$ Following suit, John Astington has observed that the Red Bull companies exploited 'a range of markets, playing styles, and repertory materials' before 'audiences of different sophistication and social composition'. Describing the 'condescension' towards the northern London playhouses as a seventeenth-century 'trope' or 'cultural fashion', he suggests that we treat references to its reputation partly as 'legends'. ${ }^{25}$

In light of these arguments and the critical reassessment of the Red Bull that is now in motion, the remainder of this paper offers a revaluation of the 1617 riot's prioritization in theatre history. It by no means intends to echo Harbage's historical account of the event, a blithe dismissal which argues that:

Theatres were sometimes molested as part of the Shrove Tuesday bacchanalia of the apprentices, one quite seriously in 1617 when the new Phoenix was badly damaged; but these outbursts have no especial significance in dramatic history. Theatres, brothels, and similar places - conspicuous and public — attracted revelers in a suggestible mood. Churches and citizens' houses were naturally immune, and something had to be destroyed. ${ }^{26}$

Rather, given the riot's role in the construction of audience taste and repertory content, this essay provides new historical contexts for the events of the 1617 Shrove Tuesday and re-examines the evidence to offer the riot context beyond theatre-historical interpretations. This work has two aims: the first, to add nuance to repertory-driven readings of the riot and qualify its central role in the stories of amphitheatre and hall playgoing and repertories; the second, to negotiate with readings of early modern drama that prioritize audience demand as determinate of repertory composition, and that tend to measure the value of the Red Bull repertory insofar as it appealed to plebeian patrons. ${ }^{27}$ As the transfer of repertory in 1617 shows, repertories were portable, and deliberately so. There is a strong case to be made for not tying them 
too closely — or with too much permanence — to their original conditions of production.

A first crucial step is to determine the relationship between the Red Bull audience and the apprentice rioters present on that Shrove Tuesday of 1617, for the argument for a repertory-motivated riot suggests that they were the same. The notion of a core audience, made up of regular patrons who were able to develop a strong sense of their 'favourite' drama, is also a key component in the narrative. K.E. McLuskie, Eva Griffith, and others have often observed the 'local' themes of the Red Bull plays, with their attention to matters of topical interest and immediate resonance for a specific audience base, but any concrete conclusion so far as audience composition and loyalty are concerned is hard to pin down from the evidence of repertory content. ${ }^{28}$ Identifying the playgoing habits of the poorer members of society who tended not to record their daily activities in letters is a difficult task, but the surviving evidence relating to theatre audiences and citizens suggests relatively mobile patrons who were free, for the most part, to choose between venues. Evidence of diverse audiences travelling to the theatre occurs in relation to the 'special case' of $A$ Game at Chess, of which John Chamberlain wrote to Dudley Carleton that the play 'hath ben followed with extraordinarie concourse, and frequented by all sorts of people old and younge, rich and poore, masters and servants, papists and puritans, wise men et.ct., churchmen and statesmen'. ${ }^{29}$ Chamberlain's choice of the word 'followed' is telling, but so is the fact that he describes the theatrical event as a 'wonder' that lasted an extraordinary 'nine dayes' and attracted an unusual amount of attention. Poorer audiences may not have been as mobile as those who could afford transport, and Gurr's observation that '[i]nhabitants of the suburbs to the north and east of the city, where the Fortune, Curtain, and Red Bull operated, were the poorest in London while the Blackfriars was the wealthiest district' is clearly relevant when considering the probable social composition of the audiences. ${ }^{30}$ Yet Margaret Pelling has found that Londoners of all social levels were subject to a 'mode of metropolitan living which was mobile, the effect of constant movement in and out of the city on a periodic, even daily basis'. ${ }^{31}$ Patricia Fumerton has similarly described the ways in which 'Business, pleasure, and the pursuit of health lured and drove Londoners back and forth', as it does today, to create a city that was well traversed by its inhabitants, even those who belonged to particular communities. ${ }^{32}$ The expected mobility of audiences is corroborated by Roslyn Knutson's analysis of the commercial interplay between different repertories, which suggests that audiences travelled to see plays at 
various venues, and that repertory strategies often depended upon an audience's familiarity with drama produced at a range of playhouses. ${ }^{33}$ Astington's analysis of the Red Bull repertory supports such findings, concluding that the Red Bull companies were not only 'guardians of old dramatic and theatrical traditions' but also 'competitive players in a market'; their offerings capitalized on dramatic trends that emerged from the theatres south of the river, while developing their own. ${ }^{34}$

In the past, scholars have also expressed uncertainty regarding the presence of apprentices at the amphitheatres, the over-zealous youth thought to have instigated the riot. Ann Jennalie Cook was the first to revaluate the apprentice constituency at playhouses, suggesting that it is unclear how apprentices could have afforded, either in time or money, to visit the theatres frequently enough to have felt an affinity with any of their repertories. ${ }^{35}$ This conclusion has been moderated since by the painstaking work of Paul Seaver and Joan Lane on the working hours and means of the apprentices, ${ }^{36}$ though Robert Ashton has independently suggested that 'the personnel of the mobs which occasionally vented their wrath or envy on theatres, victualling houses and brothels seem quite distinct from those sampling the pleasures of such establishments. ${ }^{37}$ Ashton is unable to cite sufficient evidence here to support his claim, though his point does raise the problematic absence of evidence that survives to directly link the 1617 riot on the Cockpit to playgoing, or to playgoers specifically.

Evidence concerning the composition of rioting crowds is more plentiful, though the problem of defining both riots themselves, and the rioting crowd, is a recurrent theme in historical analysis. A 'riot' is assumed to denote an event differentiated from 'riotous' behaviour, street brawls, personal attacks or political demonstrations - all events on a spectrum of disturbances to the peace in Stuart London. Rioting could technically encompass both the 'unlawful assemblies' of 1595, one of which erupted on Tower Hill and resulted in the execution of five men, and, at the other end of the scale, the case of four men tried for 'rioutouslie pullinge downe an old shedd neere the duckinge pond in the night tyme' in 1628.38 Questions of how to measure the importance, impact, and scale of rioting also abound. Theatre historians might take loss of life into account, yet this approach fails to account for the accomplishment of other, non-violent aims — aims that are often unrecorded, and remain intractable.

There are also problems with the nature of evidence that survives on London rioting, much of which consists in recognizances, gaol delivery registers, 
and summons from the Middlesex courts - documented in either the Sessions Rolls or County Records compilations. While entries are often formulaic in structure, the terminology applied to rioting and disruption is varied: 'mutinies and assemblies', 'outrages', 'misdemenours', 'affrays', 'great disorder', 'riotous assault', and 'tumult' are among the most common descriptors. Changes in official attitudes to riots further complicate the way they have been reported, alongside the personal and professional agendas of those few on whose testimony we must rely. Steven Rappaport has noted that legal records and council acts are 'couched in language intended to motivate constables and householders to be more vigilant ... and for that reason they are probably somewhat exaggerated', while Anthony Fletcher and John Stevenson have observed that local JPs might avoid reporting disturbances if they feared that doing so might reflect adversely upon their efficacy or local popularity. ${ }^{39}$ Given these historical issues, it is difficult to measure or fully assess how representative or not the 1617 riot was, and the nature of the relationship that it had to riots that occurred in the same historical period.

The special case of Shrove Tuesdays, which served as vehicles of festivity and misrule before the abstinent Lenten period set in, further complicates this obstacle. Shrove Tuesdays specifically accumulated a reputation for apprentice violence over the Stuart years, with riots in 1606, every year from 1612 to 1618, and 1626. Roger Manning has argued that this kind of sustained, annual rioting pattern was a relatively recent phenomenon in 1617, only about ten years old by the time of the Cockpit riot. ${ }^{40}$ Yet while Shrove Tuesday rioting may not have laid claim to ancient prescriptive rights or traditions, its notoriety had been established. J.C. Scott has argued that crowd action requires 'the development of an enabling popular tradition' (such as the reputation that Shrove Tuesdays were accumulating), and suggests, in an appropriately theatrical metaphor, that once popular culture has incorporated the tradition 'the riot becomes something like a scenario, albeit a dangerous one, enacted by a large repertory company whose members know the basic plot and can step into the available roles' ${ }^{41}$ Apprentices played a crucial part in this choreographical construction of riot; released on holiday, the energetic male youth of London became vigilantes, conscientious citizens determined to exact justice. ${ }^{42}$ Apprentice-led riots of the period have developed qualities and a reputation that privilege them above others, in their communityminded, morally motivated, spirit. The pulling down of bawdy houses is a popular example, the most well documented case of which involved Mrs Leakes's brothel in Shoreditch, which was dismantled on Shrove Tuesday for 
three consecutive years from 1612. Thomas Dekker in The Owles Almanacke (1618) and John Stow both refer to this occurrence as a tradition. ${ }^{43}$ Accounts of early modern society now widely incorporate the adolescent subculture of apprenticeship, representative of the 'uproarious voice of the community's conscience', and scholarship provides ample evidence for the role of theatre in encouraging romantic or heroic perceptions of apprentices. ${ }^{44}$ The narrative has, however obliquely, supported the idea of a repertory-motivated riot in its depiction of a band of young men determined to avenge the Red Bull audience, and return the repertory to its original patrons by disabling the Cockpit and forcing Queen Anne's Men back to the amphitheatre. ${ }^{45}$

Yet envisioning the crowd of Cockpit rioters as a homogenous collective with identifiable aims is problematic, even if one grants the presence of apprentices in both the audience and rioting crowd. John Walter and Michael J. Braddick have suggested that 'the crowd' in riots should not be treated as 'an overly reified surrogate for popular political consciousness', and that 'In reality, there were crowds, not one crowd', which varied in composition and motivation. ${ }^{46}$ This observation is crucial, given the uncertainty over the proportion of apprentices involved in the 1617 riot. The privy council's order to tighten authority in London refers to the participants as 'a disordered multitude, of which, though many were apprentices, yet the greatest number were rogues and vagrant persons. ${ }^{47}$ John Chamberlain makes a similar correction in his account: 'the prentises, or rather the unruly people of the suburbs'. ${ }^{48}$

This distinction emphasizes the possibility for a multitude of participants and motivations in the riot. Steven R. Smith has noted that there existed 'a body of several thousand youths who bore the apprentice imprint, and who might be expected to act with the apprentices on occasion, or even take a leading role. ${ }^{49}$ Reports of riots over the Tudor and Stuart years amply document the diversity of rioting crowds. Of the riot in 1595 at Tower Hill, John Stow comments that 'the late unlawfull assemblies and routs were compounded of sundry sorts of base people, some prentices, and some other wandring idle persons, of condition, Rogues and vagabonds. ${ }^{50}$ The young and dispossessed were not the only people actively involved in rioting: court cases most commonly document yeomen and craftsmen - freemen of the city. The Shrove Tuesday riot on Mrs Leakes's brothel in 1613 involved both masters and servants; women might also get involved. ${ }^{51}$ Discharged soldiers and disgruntled sailors were also recurrent factions in city riots. Though their involvement was usually related to wages, they also rallied for the release of prisoners, and in 1642 it was reported that 100 sailors gathered to pull down 
houses rumoured to be brothels. ${ }^{52}$ The students of the Inns of Court another distinct social category - were also known to take part in public demonstrations: usually in relation to matters that directly involved them, but sometimes as a result of spontaneous participation as riots arose..$^{53}$

The diversity of rioting crowds renders the identification of the Cockpit rioters with any one group extremely difficult, when the crowd was more likely to have consisted of a number of factions with potentially compatible, or otherwise variant, interests. The repertory-motivated riot suggests that participants were united through their shared interest in the theatrical fare of the Red Bull, but this suggestion lends a purpose and design to the attack that is complicated by the wider context of rioting, and its diffuse and impulsive nature. Even the privy council recognized the opportunistic nature of rioting. In 1617, they took note of the 'exceedinge greate multitude of vagrant rogues gathered together, as there are allwayes about this citty, ready for any mischiefe upon any occasion', who are 'apt, upon every occasion for praye and pillage, to joyne in riotous tumultes'. ${ }^{54}$

The immediate context of the riot also qualifies its specificity to theatre and repertory. Theatre-historical accounts of the 1617 riot understandably focus on the damage done to the Cockpit theatre, but in doing so tend to omit details that direct attention elsewhere. The contemporary sources describe other sites of riot occurring elsewhere in London and at the same time as the Cockpit riot. Chamberlain writes of riots that day 'in divers places, as Finsburie feilds, about Wapping by St Katherines, and in Lincolns Ynne fields, in which places beeing assembled in great numbers they fell to great disorders in pulling downe of houses'. According to Chamberlain, eight buildings beside the Cockpit suffered the same fate: 'in Finsburie they brake the prison and let out all the prisoners, spoyled the house by untiling and breaking downe the roofe and all the windowes and at Wapping they pulled downe seven or eight houses and defaced five times as many, besides many other outrages as beating the sheriffe from his horse with stones. ${ }^{55}$ Once we consider the 1617 riot in the context of that day's events and within a historiography of London violence more generally, the evidence appears much less conclusive.

One compelling feature of the Cockpit riot, however, was its attempted repeat the following year. In 1618, a letter to the lieutenants of Middlesex related 'sedicious lybells ... to Summon others in the Skirtes and Confynes, to meete at the ffortune, and after that to goe to the Playhouses the Redd Bull, and the Cock Pitt, wch they have designed to rase, and pull downe. ${ }^{56}$ This anticipated sequel to the riot was never enacted. The rumour does 
suggest premeditated riot on specific targets, though the motivations for doing so are unclear. If theatre and repertory were as important to citizens as the riot narrative suggests, an attack on the Red Bull alongside the Cockpit seems counterintuitive. Yet the letter of 1618 has cast retrospective meaning on the 1617 riot, bolstering the argument that the attacks were linked by a shared motivation and level of conscious direction. Attacks were to take place on two theatres in 1618, but this need not suggest that the repertory was responsible; though intriguing, the fact that the Red Bull and Cockpit shared the performance of a repertory in common is not explanatory in itself.

Finally, it is clear that, despite the Red Bull repertory's implied specificity to its citizen and apprentice audience, the Red Bull and Cockpit did indeed claim a repertory in common. Given the reputation of the Red Bull as a theatre 'often stereotyped as the low-status home of low-brow entertainment', the transfer of its repertory to the Cockpit has important consequences in criticism for the identification of repertory with audience and theatre. ${ }^{57}$ It raises the question of whether it was commercially viable, and aesthetically acceptable, to carry the repertory of one theatre to another and perform it there successfully, given that a different set of playgoers frequented those theatres. Differences in audience between the Red Bull and Cockpit, which theatre historians think to have been pronounced, exacerbate the issue. Historical accounts juxtapose the amphitheatre Red Bull, catering for its allegedly plebeian and culturally negligible audience, with the smaller, indoor Cockpit, the admission fees of which ensured a clientele with more disposable income. The establishment of different audience bases has also come to represent marked divisions in aesthetic taste, which are linked to expectations of audience demand based on literacy and education, and reflected in the content of each theatre's repertory. The Cockpit's inflated entry prices have suggested a more sophisticated audience of refined tastes than that found in the pit of the Red Bull. The Cockpit audience also contained 'ladies' who 'wanted neither battles nor noise, let alone blood' - a construction in which the plays of James Shirley, which have become almost synonymous with the later Cockpit repertory, feature largely. ${ }^{58}$ Here, audience reception is an active and determining condition of production.

Equally important is the extent to which the physical spaces of the venues play an instrumental role in the perceived correspondence of audience, taste, and theatre type. The diminished and enclosed space of the Cockpit, which appears to have curtailed the dramatic use of trumpets, drums, and battle-scenes, contrasts with the weathered and war-strewn stage of the open 
and capacious Red Bull. Scholarship is gradually breaking down the binary between the amphitheatres and the hall-playhouses, and the assumptions concerning the aesthetic appeal of their plays to particular audiences - particularly in relation to analysis of the King's Men's repertory strategy. Critics now widely accept that Shakespeare's 'Globe plays transplanted to the Blackfriars unchanged, as his Blackfriars plays transplanted to the Globe. ${ }^{59}$ Yet critical treatments of the more marginalized Red Bull and Cockpit remain suggestive of the bifurcation of audiences and taste that, though now responsibly qualified, has remained attendant on theatre history in some form since Alfred Harbage's Shakespeare and the Rival Traditions. ${ }^{60}$

The riot, when read as an act of reception - explicitly one of rejection of Beeston's new repertory strategy — implies that the Red Bull patrons felt that the transfer of repertory was significantly misjudged. Yet positioned against prevailing notions of the kind of repertory that a Cockpit audience would have found acceptable, the repertory-motivated riot has potentially wider implications. Not only does it underscore the Red Bull repertory's identification with an amphitheatre audience, it does so at the risk of distancing it further from its eventual destination at the Cockpit. The amphitheatre origins of the Cockpit repertory have been difficult to reconcile for some critics, given that the indoor playhouse's appropriation of the Red Bull repertory disrupts the traditional binary of the early modern audience dynamic. ${ }^{61}$ According to the commonplace division between hall-playhouse and northern-amphitheatre fare, the Cockpit repertory's Red Bull origins appear problematic rather than liberating. Beeston's transfer of repertory reads, in this context, as a decisive rupture in the accepted patterns of theatre history: a transgression in repertory management so marked that it prompted civil unrest.

Yet while the riot is already recognized as a singularly damaging and controversial aspect of the Cockpit theatre's history, this notion need not extend to the interpretation of its repertory strategy. ${ }^{62}$ The relocation of repertory from the Red Bull to the Cockpit was in fact ultimately successful. Beeston's approach to repertory management shows that audience composition did not define the commercial success of his companies, and that a repertory composed largely of Red Bull revivals, and apparently sought after by a plebeian audience base, did not alienate apparently up-market customers. The repertory of Queen Henrietta's Men in particular — the company of lengthiest tenure at the Cockpit — directly contradicts reception-based accounts that emphasize incompatibility between the fare of distinct theatre types. The company inherited a large stock of Red Bull revivals, and accumulated at 
least two plays written for the Prince's Men at the amphitheatre Fortune. ${ }^{63}$ As Andrew Gurr's detailed discussion of the relationship between the Red Bull and Cockpit describes, 'the two playhouses became distinct in the social composition of their audiences more through their prices and their locality than their repertoire'; the Cockpit repertory was a strong competitor to the Blackfriars precisely because it provided for the '[c]onservatism' and ' $\mathrm{t}]$ raditional preferences' of the hall-playgoing public. ${ }^{64}$ This discussion clearly manifests the convergence, rather than bifurcation, of allegedly 'public' and 'private' repertories. In doing so it offers a basis from which to interrogate the widely-held assumption that different audiences demanded qualitatively different plays - that the boisterous, 'teare-throat' drama of the Red Bull was suitable and desirable only for fishwives and apprentices, and that audience, theatre, and repertory were always mutually defining.

This paper hopes to establish that reading the 1617 riot on the Cockpit in terms of repertory management and audience satisfaction is not as inevitable as has previously appeared. Attention to the riot and its place in criticism helps to define the axes of audience along which theatre historians often direct interpretation of early modern theatre and repertory. Considering the riot within its historical context displaces it from its central position in theatre history, and at the same time suggests new ways of thinking about repertory that do not hinge as fixedly around constructions of audience taste. The 'drum-and-trumpet' plays of the Red Bull were not as specific to the Red Bull, its admission prices, or its clientele, as the ferocious audience demand expressed by the riot has tended to suggest. Instead, these plays helped create the conditions for the formation and success of Queen Henrietta's Men: one of the most important hall-based companies in theatrical London. Deconstructing the riot's privileged relationship to theatre enables the recognition of repertory strategies in which the original conditions of production neither defined nor limited plays, which could be relocated and revived successfully across both theatre spaces and audiences.

What Beeston's repertory strategy suggests about the theatrical marketplace in 1617 is rather less clear, however, given that the desire to move 'upmarket' seems to be a legitimate description of his enterprise. The ambition to target the 'elite' audiences, amongst whom the boy companies were proving so popular in the 1590 s, is certainly the motivation that Tom Rutter attributes to the Chamberlain's Men's acquisition of the Blackfriars playhouse. ${ }^{65}$ Yet Beeston broke from the Chamberlain's/King's Men model of alternating between an indoor and outdoor theatre. Maintaining an interest in the Red 
Bull, he allowed the Red Bull and Cockpit companies to run in tandem, but as separate ventures. ${ }^{66}$ No evidence exists of continuity across the repertories beyond 1617, and there is no indication of cross-company interaction. Given the precedent of the King's Men, who maintained a 'bifold' appeal to up- and down-market audiences through the use of two playhouses and their shared repertory, Beeston's reasons for maintaining a distance between the companies performing at the theatres he owned remains a pressing question. ${ }^{67}$ The lessening inclination of the master of the revels to invite the amphitheatre companies to court after around 1615 might explain Beeston's move towards the indoor hall-playhouse market (and in turn might have encouraged Herbert's policy, as conscious or unconscious as it may have been). ${ }^{68}$ Another obvious benefit of maintaining independent companies was the opportunity that this offered for two separate, year-round seasons, rather than closing each theatre for half the year, as the King's Men's dual-theatre strategy required. Perhaps the most important consequence of the split that Beeston initiated in 1617 was the opportunity it provided for two distinct company identities to emerge. And crucially, this distinction was not grounded in a qualitative difference in repertory. This lack of difference raises questions concerning which qualities or assets in the theatrical marketplace defined reputation and identity — and how these qualities may have changed over time, for the process is unlikely to have been stable. For Beeston, the question of how to maintain a competitive edge in the marketplace — both commercial and at court — was clearly paramount. But in 1617 it seems at least possible that theatrical reputations did not owe quite as much to the repertory's aesthetics and content as might be expected, or as theatre history has so far maintained.

Eleanor C. Collins

\section{Notes}

I would like to thank Tom Rutter for his help, encouragement, and patience while working on this publication, Andrew Gurr for his invaluable comments, and Keith Lindley for sharing with me his expertise on London riots.

1 'A Letter to the Lord Major and Aldermen of London, and Commissioners of Oyer and Terminer in the Citty of London and Countye of Middlesex', 5 March 1617, Acts of the Privy Council, 1616-1617 (London, 1927), 175. 
2 Letter of Edward Sherbourne, 8 March 1617, G.E. Bentley (ed.), The Jacobean and Caroline Stage, 7 vols (Oxford, 1941-1968), 6.54.

3 Ibid, 54.

4 Letter of John Chamberlain to Dudley Carleton, 8 March 1617, The Letters of John Chamberlain, Norman Egbert McClure (ed.), 2 vols (Philadelphia, 1939), 2.59-60.

5 'A Letter to the Lord Major and Aldermen of the Citty of London', 16 March 1617, Acts of the Privy Council, 1616-1617, 193-4.

6 Ilana Krausman Ben-Amos, 'Service and the Coming of Age of Young Men in Seventeenth-Century England', Continuity and Change 3 (1988), 41-64; Steven R. Smith, 'The London Apprentices as Seventeenth-Century Adolescents', Rebellion, Popular Protest and the Social Order of Early Modern England, ed. Paul Slack (Cambridge, 1984), 219-31; Bernard Capp, 'English Youth Groups and The Pinder of Wakefield', in Slack (ed.), 212-19.

7 K.J. Lindley, 'Riot Prevention and Control in Early Stuart London', Transactions of the Royal Historical Society, 5th series, 33 (1983), 109-27, refers to the day of the 1617 riot as the 'blackest Shrove Tuesday' (110).

8 Charles J. Sisson, 'The Red Bull Company and the Importunate Widow', Shakespeare Survey 7 (1954), 68. Note that G.E. Bentley remained impartial to the riot's causes, and wrote of Sisson's interpretation that 'it seems to me excessively precise and informed for thousands of rioters in several parts of London' (The Jacobean and Caroline Stage, 6.56).

9 For the most recent development, see Mark Bayer, 'Moving Upmarket: Queen Anne's Men at the Cockpit in Drury Lane, 1617', Early Theatre 4 (2001), 138-48.

10 Andrew Gurr, The Shakespearean Stage, 1574-1642, 3rd edn (Cambridge, 2001), 14.

11 In the event, the company were forced to return to the Red Bull while the Cockpit was being rebuilt - an enterprise that resulted in the popular renaming of the theatre as the Phoenix (Bentley, The Jacobean and Caroline Stage, 1.163). Gurr emphasizes the apparent permanency of the transfer in Playgoing in Shakespeare's London, 3rd edn (Cambridge, 2004), 179.

12 Bayer, 'Moving Upmarket', 139.

13 Scott McMillin and Sally Beth Maclean, The Queen's Men and Their Plays (Cambridge, 1998), xii-xiii; Lucy Munro, 'Governing the Pen to the Capacity of the Stage: Reading the Red Bull and Clerkenwell', Early Theatre 9.2 (2006), 110.

14 For 'teare-throat', see Edmund Gayton, Pleasant Notes upon Don Quixot (London, 1654), 24; for the 'meaner sort of People', see James Wright, Historia Histrionica: An Historical Account of the English Stage (London, 1699), 5; for the Red Bull's reputation see Bentley, The Jacobean and Caroline Stage, 6.240-7. 
15 John Webster, The White Divel (London, 1612), Ar; Thomas Dekker, If It Be Not Good, the Diuel Is in It (London, 1612), A4.

16 Marta Straznicky, 'The Red Bull Repertory in Print, 1605-60', Early Theatre 9.2 (2006), 148.

17 Evidence concerning the behaviour of some of the Red Bull audience has suggested a clientele accustomed to wreaking havoc, which has complemented the riot interpretation. The representational capacity of these accounts is limited, but see Bentley, The Jacobean and Caroline Stage, 6.239, for sensationalist anecdotes.

18 F.S. Boas, Thomas Heywood (London, 1950), 55.

19 Arthur Melville Clark, Thomas Heywood, Playwright and Miscellanist (Oxford, 1931), 222.

20 Bentley, The Jacobean and Caroline Stage, 4.712.

21 To the contrary, Gurr's analysis of the relationship between the Red Bull repertory and the Cockpit theatre accommodates and emphasizes the 'older and more openly citizen repertoire' of the Cockpit (Playgoing, 177), and questions the role of audience and repertory in defining the status of the theatres: 'It is not quite clear how far it was the apprentice patrons or how far the apprentices' favourite plays that gave the Red Bull its reputation ... since the Cockpit often ran Red Bull plays for its privileged audiences', The Shakespearean Stage, 15.

22 Gurr, Playgoing, 204.

23 Munro, 'Governing the Pen', 101.

24 Straznicky, 'The Red Bull Repertory', 146, 144, 150.

25 John Astington, 'Playing the Man: Acting at the Red Bull and the Fortune', Early Theatre 9.2 (2006), 138, 140, 130.

26 Alfred Harbage, Shakespeare's Audience (New York, 1941), 107.

27 See notes $18-20$.

28 For instance, see K.E. McLuskie on the 'citizen' concerns of plays performed at the Red Bull and Fortune in her Dekker and Heywood (Basingstoke, 1994), 54-74; Eva Griffith's unpublished PhD thesis, 'Playhouse, Company, Repertoire: The Queen's Servants at the Red Bull Theatre, Clerkenwell (c. 1605-1609)', also situates the drama in the specific context of its geographical and social location (King's College London, 2003).

29 Letter of John Chamberlain to Dudley Carleton, 21 August 1624, The Letters of John Chamberlain, McClure (ed.), 2.578.

30 Gurr, Playgoing, 170.

31 Margaret Pelling, 'Skirting the City?', Londinopolis: Essays in the Culture and Social History of Early Modern London, ed. Paul Griffiths and Mark S.R. Jenner (London, 2005), 154. 
32 Patricia Fumerton, Unsettled: The Culture of Mobility and the Working Poor in Early Modern England (Chicago, 2006), 13.

33 Roslyn Lander Knutson, Playing Companies and Commerce in Shakespeare's Time (Cambridge, 2001), 11, 35-6, 63, 148-9.

34 Astington, 'Playing the Man', 132-3.

35 Ann Jennalie Cook, The Privileged Playgoers of Shakespeare's London, 1576-1642 (Princeton NJ, 1981), 218-21.

36 Paul Seaver, 'A Social Contract? Master Against Servant in the Court of Requests', History Today 39 (1989) 53; Paul S. Seaver, 'Work, Discipline and the Apprentice in Early Modern London', Wellsprings of Achievement, ed. Penelope Gouk (Hampshire, 1995), 161-2; Joan Lane, Apprenticeship in England, 1600-1914 (London, 1996), $101-3$.

37 Robert Ashton, 'Popular Entertainment and Social Control in Later Elizabethan and Early Stuart London', London Journal 9 (1938), 7.

38 John Stow, Annalles, or, a Generall Chronicle of England, augmented by Edmund Howes (London, 1631), 769-70; Middlesex County Records, 4 vols, ed. John Cordy Jeaffreson (Clerkenwell, 1888), 3.164.

39 Steven Rappaport, Worlds Within Worlds: Structures of Life in Sixteenth-Century London (Cambridge, 1988), 10; Anthony Fletcher and John Stevenson, Order and Disorder in Early Modern England (Cambridge, 1985), 28.

40 Roger Manning, Village Revolts (Oxford, 1988), 211.

41 J.C. Scott, Domination and the Arts of Resistance (New Haven, 1990), 151.

42 Michael J. Braddick and John Walter, 'Grids of Power: Order, Hierarchy and Subordination in Early Modern Society', Negotiating Power in Early Modern Society, ed. Braddick and Walter (Cambridge, 2001), 23; Ben-Amos, 'Service and the Coming of Age', 52-7.

43 Middlesex Sessions Records: Calendar to the Sessions Records, n.s.1 (London, 1935), 1.31, 371, 389; The Letters of John Chamberlain, 2.339; Thomas Dekker, The Owles Almanacke (London, 1618), 8; Stow, Annalles, 1026.

44 Braddick and Walter, 'Grids of Power', 23; Paul S. Seaver, 'Declining Status in an Aspiring Age: The Problem of the Gentle Apprentice in Seventeenth Century London', Court, Country and Culture, ed. Bonnelyn Young Kunze and Dwight D. Brautigam (Rochester, 1992), 129-48; Chris Fitter, 'The Quarrel is between Our Masters and Us Their Men: Romeo and Juliet, Dearth, and the London Riots', English Literary Renaissance 30 (2000), 156; Smith, 'The London Apprentices', 226. Roger Manning has enquired whether Shrove Tuesday rioting was itself 'an invention of the Jacobean playwrights, which the London apprentices emulated' (Village Revolts, 212).

45 See Bayer, 'Moving Upmarket', 138-48. 
46 Braddick and Walter, 'Grids of Power', 8.

47 'A letter to the Lord Major and Aldermen of the Citty of London', 194.

48 The Letters of John Chamberlain, McClure (ed.), 2.59.

49 Steven R. Smith, 'The Social and Geographical Origins of the London Apprentices 1630-1660', The Guildhall Miscellany 4 (1973), 198.

50 Stow, Annalles, 770.

51 Middlesex County Records, Jeaffreson (ed.), 2.49; Middlesex Sessions Records, 1.287, 4.100 .

52 Lindley, 'Riot Prevention', 113.

53 Ibid; Manning, Village Revolts, 214.

54 Acts of the Privy Council, 1616-1617, 8 March and 16 March 1617.

55 The Letters of John Chamberlain, McClure (ed.), 59-60.

56 Bentley, The Jacobean and Caroline Stage, 6.377.

57 Munro, 'Governing the Pen', 100.

58 Gurr, The Shakespearian Playing Companies (Oxford, 1996), 132; Richard Levin, 'Women in the Renaissance Theatre Audience', Shakespeare Quarterly 40 (1989), 165-74.

59 Gurr, Playgoing, 201.

60 Alfred Harbage, Shakespeare and the Rival Traditions (Bloomington, 1952).

61 Most often, critics do not acknowledge its Red Bull origins and link the Red Bull plays only to their original venue. See Bentley above on The Seven Champions of Christendom, the paradigm of Red Bull fare despite its title-page's claim to performance at the Cockpit; Bayer on If You Know Not Me, which deliberately 'popularises history' for the Red Bull's 'often raucous audiences', 'Staging Foxe at the Fortune and Red Bull', Renaissance and Reformation 27 (2003), 62; and Clark on the 'dramatic monster' that is Heywood's The Rape of Lucrece - 'definitely a popular presentation of a classical plot for a Red Bull audience, to whom symmetry, restraint, form, and congruity were less intelligible than sentiment, tragical speeches, ribaldry and the rest of the olla podrida of the plebeian theatres', Thomas Heywood, 220.

62 Bentley writes that the 'vandalism' of the riot (which for him was circumstantial) 'surely accelerated' the 'decline' of Queen Anne's Men, and that 'no prosperity or great reputation is associated with their next two years at the Phoenix'; see his entry in The Revels History of Drama in English (New York, 1981), 3.89.

63 Rowley and Middleton's The World Tossed at Tennis and A Fair Quarrel. Rowley's All's Lost by Lust is also a candidate; Bentley, The Jacobean and Caroline Stage, 5.1019-20.

64 Gurr, Playgoing, 182.

65 Tom Rutter, Work and Play on the Shakespearean Stage (Cambridge, 2008), 97-8. 
66 Beeston is one of six men at the Red Bull named in an order for repair of the highways by the theatre, dated 3 October 1622; see Bentley, The Jacobean and Caroline Stage, 1.169 n.2. As he had managed Queen Anne's Men there, and returned there with them after the 1617 riot, it appears that he owned, and continued to own, the theatre.

67 For 'bifold appeal' see discussion in Rutter, Work and Play, 110.

68 Exceptions include the Red Bull Revels' Two Merry Milkmaids, at court in 1619/20, and Gramercy Wit in 1621; see Bentley, The Jacobean and Caroline Stage, 1.173.

\section{Romeo at the Rose in 1598}

In two plays of the Lord Admiral's Men - Englishmen for My Money and The Two Angry Women of Abingdon - echoes of Romeo and Juliet appear. ${ }^{1}$ The first performances of Englishmen took place at the Rose in 1598. Two Angry Women is likely to have played at the same venue in the same year. What may these echoes tell us about the ethos and practices of the Lord Admiral's Men, about the dramatists who wrote for them, and about the company's place in the literary and dramatic milieu of the time?

I want to argue that the presence of these echoes reveals a degree of integration into urban literary fashion. And I will also suggest that some of the company's playwrights exhibit the kind of knowing playfulness that was soon to characterize the repertory of the children's companies and which was already shaping the satires and epigrams to reach print publication at this time. In other words, I suggest that those who wrote for the Admiral's company may have had more in common with the young and iconoclastic writers of verse satire and of experimental drama for the indoor companies than commentators have often thought.

The Admiral's Men, theatre historians frequently assume, had a repertory aimed at non-elite audiences. One line of thought, which Roslyn Lander Knutson vividly and critically summarizes in The Repertory of Shakespeare's Company 1594-1613, contrasts the Admiral's repertory with that of the Lord Chamberlain's Men. A heightened regard for Shakespeare's company colours this distinction, with the purveyor of formulaic plays set against the sponsor of sublime drama, while our access to Henslowe's papers, with their starkly commercial concerns, underpins the contrast. ${ }^{2}$ The binary is still in evidence in the work of Andrew Gurr, who in Playgoing in Shakespeare's London takes 